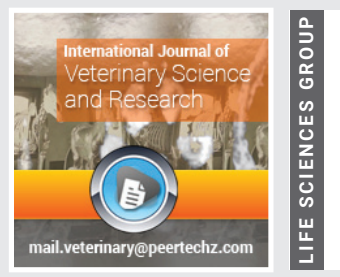

\title{
Biomass production and nutritive value of Sida alba leaves fed to desert sheep
}

\section{Mohammed Alhadi Ebahiem*, Hajir Hamed1, Salah Abulgabar Salah Bukhari², Suleiman Eshag Abdalla Mohamed $^{3}$, Salah Basar Hammad Dahia ${ }^{3}$ and Jumaa Barram Jadalla $^{1}$}

'Department of Animal Production, Faculty of Natural Resources and Environmental Studies, University of Kordofan, Sudan

${ }^{2}$ Department of Animal Production, Faculty of Natural Resources and Environmental Studies, University of Alsallam, Alfula, Sudan

${ }^{3}$ Department of Animal Production, Faculty of Agriculture Sciences, University of Dalanj, Sudan
Received: 02 December, 2021

Accepted: 30 December, 2021

Published: 31 December, 2021

*Corresponding author: Mohammed Alhadi Ebrahiem, Department of Animal Production Faculty of Natural Resources and Environmental Studies, University of Kordofan, Sudan, E-mail: mahaali5656@gmail.com

ORCID: https://orcid.org/0000-0003-3545-1242

Keywords: Biomass production; Nutritive value; Sida alba leaves; Animal feeding; Desert sheep

Copyright License: (c) 2021 Ebahiem MA, et al. This is an open-access article distributed under the terms of the Creative Commons Attribution License, which permits unrestricted use, distribution, and reproduction in any medium, provided the original author and source are credited.

https://www.peertechzpublications.com

\section{Check for updates}

\begin{abstract}
The study was established to study the effects of supplementation with Sida alba leaves on feed intake, nutrient digestibility, live body weight changes of Sudanese Desert lambs. Fifteen Lambs of 4-6 months old and weighing $18 \pm 500 \mathrm{~kg}$ were divided into three similar groups each with five animals. Seven days were allowed for adaptation. The lambs were weighed weekly for 8 weeks. Daily feed intake was obtained by subtracting the remained amounts from quantities offered the day before. Feces were collected at the last ten days for determination of nutrients digestibility coefficients via total feces collection method. The data were analyzed using analysis of variance. Differences among means were detected using least significant difference test. The results indicated that group II that was on natural grazing supplemented with Sida alba leaves consumed significantly $(\mathrm{p}<0.01)$ greater amount of feed compared to group I that was on the natural grazing only and group III supplemented with a concentrate ration feed intake was $1316,730,1381,500$ and $1207.650 \mathrm{~g}$ for group I, II and III, respectively. No significant differences (P $\geq 0.05$ ) in digestibility coefficients of all nutrients between group II and III but group I had lowers coefficients than II and III. Total and daily body weight was higher in group II and III when compared with group I. The biomass production was estimated to be $84.910 \mathrm{~g} / \mathrm{shrub}$ or 1.697 per hectare based on a square meter space for a plant. It was concluded Sida alba leaves could support lambs on low quality grazing.
\end{abstract}

\section{Introduction}

Sudan is characterized by multiple climates that impact the diversity of livestock where camels are concentrated in the northern belt and cows in the southern and western belts while small ruminants (sheep and goats) spread in all parts of Sudan [1]. In addition to this, the country is endowed with fisheries, poultry and equine species according to the climatic conditions. Rainfall ranges in Sudan from almost zero to $75 \mathrm{~mm}$ in arid areas to $1000 \mathrm{~mm}$, at least while temperatures ranging between 45 degrees (in summer) to 10 degrees (in winter) and agricultural land represents more than a third of Sudan area, while exploited portion does not exceed 1/5 of agricultural area.
Sudan has water resources with a variety of sources, including the possibility of water harvesting [2,3]. The importance of the livestock sector is well recognized by economists and planners. Sudan food supplier animals (cattle, sheep, goats, camels) are estimated at 105 million heads [4]. There are as well other animals and wildlife. The importance of livestock is attributed to their economic and social contributions.

Animal resources in Sudan that comprise of sheep, goats, cattle camel, poultry and wild game is mainly dependent on the natural rangelands as source of feed. Less important feed sources are crop residues, agro-industrial by-products, feed of animal origin, fodder crops and synthetic feed $[1,5,6]$. Establishing a 
competing and sustainable program for exporting live animals and good quality meat is required in order to enable Sudan facing the international trade parameters this entails a vital reed to improve the livestock production systems based on natural feed sources mainly rangelands $[7,8]$. This purpose needs to impose strict hygienic measures to provide healthy and wholesome meat to fulfill the international requirements and domestic needs. Natural grazing from rangelands provides a very good option for this purpose [9].

The rapidly growing livestock population imposes continuing pressure on this shrinking range resource. Agricultural areas, mining and urban residential places are expanding on rangeland [10]. On this limited area, the livestock population is concentrated with communal continuous grazing. The eventual result is overgrazing where palatable species are excessively consumed leading to their disappearance. Since no systematic activities are carried out to collect seeds of such nutritive and palatable species, rangeland will be turned into areas covered with species that are known to be of little acceptance to livestock species with low nutrient contents [11].

To recommend for candidate species, that high good quality and palatable species must be determined, their nutritive value be accessed before being selected for conservation. So, this study was intended to assist in the development of sustainable production systems based on natural grazing from rangelands of the country. The development of such sustainable livestock production systems is essential since natural resources especially browse tree and shrubs are the main feed source in Sudan. The direct objectives of this study is to estimate biomass production from Sida alba shrub and its nutritive value, in vitro and in Vivo digestibility and energy value of this draught resist plant for feeding animals and try to domesticate it.

\section{Materials and methods}

\section{The study area}

This study is conducted in Elobeid city- Sheikan localityNorth Kordofan state, Sudan. The state lies between the longitude $\left(29^{\circ}-34^{-}, 30^{\circ}-30^{-}\right.$East $)$and the latitudes $\left(12^{\circ}-25^{-}\right.$, $13^{\circ}-30^{-}$North) with an area of $8080 \mathrm{~km}^{2}$. This City is the capital of Sheikan locality and North Kordofan State. Sheikan is characterized by undulating plains, depressions; sand covered with hilly areas and some mountain clusters. Three climatic regions cover North Kordofan State. These are dry, semiarid dry and low rainfall savanna on sand areas. The long term average rain is between $250-400 \mathrm{~mm}$. The maximum temperature is $40-42^{\circ} \mathrm{C}$ and the minimum is $13^{\circ} \mathrm{C}$. In the semiarid region, rainfall is between $300-600 \mathrm{~mm}$ and the maximum temperature is $39^{\circ} \mathrm{C}$. The humidity reaches 1175 during the dry season. In the autumn, the air humidity reaches $65-67 \%$ [11]. Rain fall as sporadic showers in May and becomes regular from June to October. It is usually heavier in July and reaches peak in August before declining in September to reach its lower pattern in October. Temperatures are modified by rain at this time though it is hot and humid in general. Temperature and precipitation drop from the amount of evaporation in July and August and the highest rainfall recorded in 2010 was 620 mm [12]. This city is also considered the largest market for gum Arabic, as a primary and important market of livestock brought from different parts of western and Southern Sudan in a continuous movement of the presence of different types of animals. There are some food industries and Agroindustrial companies such as vegetable oil production and flour mills. Elobeid Petroleum Refinery is set at $10 \mathrm{~km}$ from the city center. In general this city is a main marketing city for the country. Rural areas are farming and livestock producing areas $[11,12]$. There are trees of Hashab (Acacia senegal), Marrekk (Boscia senegalensis) and Seyal (Acacia tortilis) in the northern regions. Southern and central parts are covered with desert palm (Balanites agyptiaca), Sidr (Ziziphus spinachristi), tebeldi (Adansonia digitata) habeel (Combretum cordofanum), kitr (Acacia mellifera), ghobeesh (Quiera senegalensis ), Haraz (Faiherbia albida ), Arrad (Albizzia amara), Aradaib (Tamarindus indica) and many other trees and shrubs species of the zones indicated above. The understorey is dominantly covered with herbs such as Alysicarpus species (Fraisha), Zornia gleochidiata (lisaig), Cassia obtusiflora (Kawal), Cassia occidentals (Soreib), Amaranethesis flavicans (Lisan eltair), Blepharis linarrifolia (Beghail), and many others. Grasses dominant in this are Eragrostis tremula (bino), Aristida pallida (gaw), Cenchrus biflorus (Huskaneet khashin), C.setigrus (Huskaneet Naeem) Pennisetum pedicellatum (Umdofofo), sida alba (mugAnimals) [3,11-14].

\section{The experimental animals}

Fifteen Desert sheep lambs are used in this study. The animals are divided into three similar groups each with five animals. The animals were individually penned, equipped with feeding and drinking troughs Prior to the commencement of treatments the animal are ear tagged and vaccinated against diseases endemic to the study area. One week is considered a preliminary adaptation period where the animals are to be adapted for feed and treatments, the adaptation period is also necessary for removal of the effects of the feed previously taken.

The animals are weighed at the beginning of trial, and once every week until end the trial to monitor their weight change as effected by type of rations.

\section{Sampling of Sida alba}

- For determination of biomass production two methods are followed. The first technique is estimate from a number of shrubs numbers of branches per shrub, weight of leaves per branch, branch and stem diameter (Figures 1,2). From the data linear equation is developed.

- For biomass estimation also forage from unit area can be estimated. This can be attained through growing the species in a plot for two months.

\section{The experimental feed}

The study is proposed to use three types of rations, these are:-

A. natural grazing and concentrate

Citation: Ebahiem MA, Hamed H, Salah Bukhri SA, Abdalla Mohamed SE, Hammad Dahia SB, et al. (2021) Biomass production and nutritive value of Sida alba 


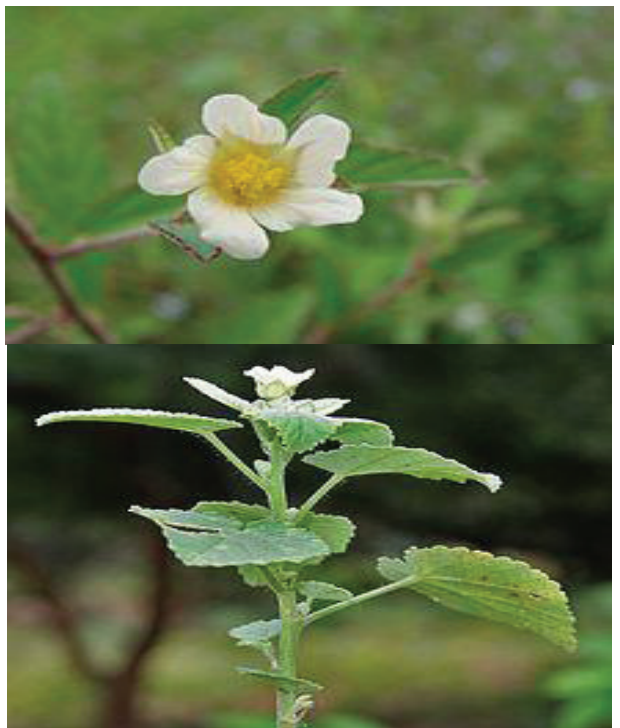

Figure 1: Flowers and leaves of Sida alba.

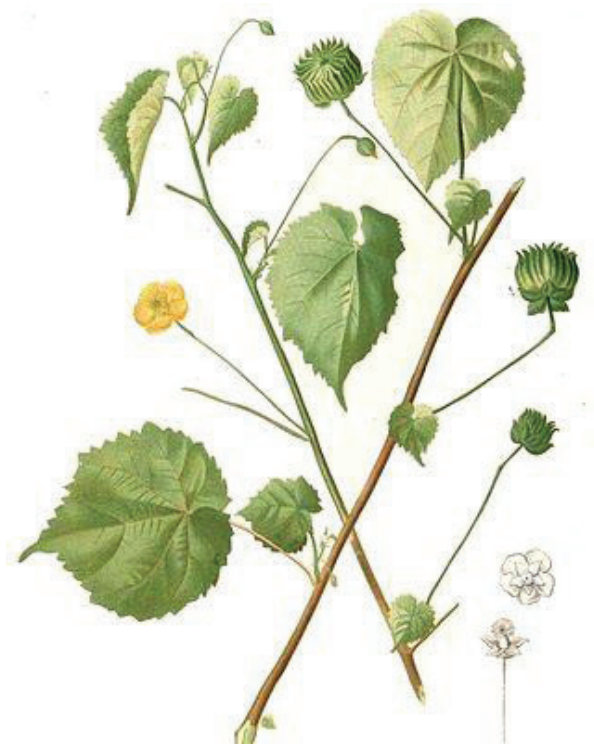

Figure 2: Branches of Sida alba

B. natural grazing and Sida alba

C. natural grazing alone.

\section{Chemical analysis}

The plant biomass is analyzed using proximate analysis, and forage fiber analysis and minerals, in vitro and in vivo digestibility analysis as described by The Association of the Official Analytical chemists [15]. In Vitro dry matter and organic matter was determined according to Telly and Terrie $(7,8)$.

\section{Statistical analysis}

The experimental design is a Complete Randomized Design (CRD) that has three treatments and five replicates. The data is analyzed using analysis of variance [16]. The difference among treatment means were detected using least significance difference test [17].

\section{Result and discussion}

\section{Chemical composition of Sida alba leaves}

The biomass productivity of Sida alba, average dry matter from Sida alba (kg/ha) and the average productivity of dry matter per plant in g/plant were estimated. Average amount of biomass per plant was estimated to be $75 \mathrm{~g}$ dry matter from one cut. Estimating that one feddan $\left(4200 \mathrm{~m}^{2}\right)$ could have a stand of 8400 plants, so the feddan area could produce 630 kilogram (1.5 ton per hectare). Since this plant is perennial, possibly more biomass could be expected if cut at intervals throughout the year.

The chemical composition of the Sida alba plant is shown in Table 1. The proximate analysis results of the biomass harvested from the plant showed that it had $83.2 \%$ Dry matter, $72.9 \%$ organic matter, $21.3 \%$ crude protein $16.23 \%$ crude fiber, $33.6 \%$ Nitrogen free extract and ether extract $1.75 \%$ when sundried and analyzed. Chemical composition ingredients used in formulation of rations usually fed to sheep was also presented in Table 1. Those ingredients are groundnut, sorghum grains, wheat bran and natural grazing. Dry matter was similar in ration I and III where ration I was natural grazing only ration III was natural grazing and concentrate. Dry Matter was lowest in ration II that was formulated with natural grazing and Sida alba leaves. The value of dry matter was $95.5 \%, 83.2$ and $94 \%$ for ration I, II and III respectively.

Organic matter was the highest in ration III (Natural grazing plus concentrate) followed by ration I (Natural grazing) and lastly ration III (Natural grazing plus Sida alba).

Crude protein was highest in ration II (22\%) where sida alba leaves were added to natural grazing while in ration III at $23.2 \%$ CP and was Next to ration II and ration I had the lowest value of crude protein.

Nitrogen-Free Extract (NFE) was the highest in ration III (Natural grazing supplemented with concentrate followed by the natural grazing and lastly that of natural grazing supplemented with Sida alba leaves.

Ether Extract (EE) was the highest in natural grazing supplemented with concentrate followed by the ration containing natural grazing plus Sida alba. The lowest EE was that of the natural grazing only.

Ash in the three rations was 7.3, 10.3 and $2.0 \%$ for natural grazing alone, natural grazing plus Sida alba and natural grazing supplemented with concentrate.

Table 1: The chemical composition of ingredients used in formulating the rations.

\begin{tabular}{|c|c|c|c|c|c|c|c|}
\hline FEED & DM & OM & CP & CF & EE & NFE & ASH \\
\hline GNSC & 90.52 & 79.55 & 23.3 & 6.5 & 4.5 & 28.55 & 10.97 \\
\hline Sorghum grains & 95.5 & 92.9 & 10.9 & 2.3 & 3.2 & 75.31 & 2.6 \\
\hline Wheat bran & 90.78 & 85.38 & 16.92 & 12.5 & 4 & 51.96 & 5.40 \\
\hline Sida alba & 83.2 & 72.9 & 21.3 & 16.23 & 1.75 & 33.6 & 10.31 \\
\hline Natural grazing & 95.51 & 88.23 & 4.11 & 37.25 & 1.23 & 48.10 & 7.28 \\
\hline
\end{tabular}

GNSC: Groundnut Seed Cake; DM: Dry Matter; OM: Organic Matter CP: Crude Protein; CF: Crude Fiber; EE: Ether Extract; NFE: Nitrogen Free Extract 
The dry matter was highest in ration I of $95.5 \%$ in comparison to $94 \%$ in ration III and $83.2 \%$ in ration II. Organic matter the highest ratio was in ration III (91\%), then rations I $(88.2 \%)$ and ration II of $72.9 \%$. Crude fibers the highest level was $37.5 \%$ in ration I in comparison to $16.2 \%$ in ration II and $2.3 \%$ in ration III. Nitrogen-free extracts of $73.9 \%$ in ration III, $48.1 \%$ in ration I and $33.6 \%$ in ration II. Ether extracts the highest ratio of $2.5 \%$ was determined in ration III (Table 2 ).

Dry matter was similar in ration I and III where ration I was natural grazing only ration III was natural grazing and concentrate. Dry Matter was lowest in ration II that was formulated with natural grazing and Sida alba leaves. The value of dry matter were $95.5 \%, 83.2$ and $94 \%$ for ration I, II and III respectively.

Organic matter was the highest in ration III (Natural grazing plus concentrate) followed by ration I (Natural grazing) and lastly ration III (Natural grazing plus Sida alba).

Crude protein was highest in ration II (22\%) where Sida alba leaves were added to natural grazing while in ration III at $23.2 \% \mathrm{CP}$ was next to ration II and ration I had the lowest value of crude protein.

Nitrogen-Free Extract (NFE) was the highest in ration III (Natural grazing supplemented with concentrate followed by natural grazing and lastly that of natural grazing supplemented with Sida alba leaves. Ether Extract (EE) was the highest in natural grazing supplemented with concentrate followed by the ration containing natural grazing plus Sida alba. The lowest EE was that of the natural grazing only. the three feed had 1.2, 1.7 and $2.5 \%$ EE for ration I, II and III respectively. Ash in the three rations was 7.3, 10.3 and $2.0 \%$ for natural grazing alone, natural grazing plus Sida alba and natural grazing supplemented with concentrate (Table 2).

\section{Effect of feed lambs with Sida alba on dry matter intake}

The effect of supplementation of Desert sheep lambs on natural grazing with Sida alba biomass on their feed intake is shown in Table 3. Significant differences $(\mathrm{P}<0.01)$ in the daily of dry matter intake was observed among the three experimental groups where group (I) that was on natural grazing supplemented with concentrate ration and group (II) fed natural grazing supplemented with Sida alba consumed greater amount of feed compared to group (III) that was fed natural grazing only. No significant differences $(P>0.05)$ could be observed in feed intake between group I and II. Daily feed intakes for the three groups were 1316.73, 1381.5, and 1207.65 g/day respectively.

\section{In vitro dry matter and organic digestibility}

In vitro Digestibility of Dry Matter (DMD) and organic matter of rations according to the amount of Sida alba is presented in Table 4. Ration I that was on natural grazing had DMD 56.45\% and Organic Matter Digestibility (OMD) at of $59.55 \%$ while the second ration natural grazing plus Sida alba had $65.67 \%$ dry matter digestibility. The third ration (natural grazing alone had $51.45 \%$. There were significant $(\mathrm{P}<0.01)$ among coefficients of
Table 2: Rations chemical composition an affected by supplementation with Sida alba leaves in the ration.

\begin{tabular}{|c|c|c|c|c|c|c|c|}
\hline Ration & DM & OM & CP & CF & NFE & EE & ASH \\
\hline I & 95.5 & 88.2 & 4.11 & 37.5 & 48.10 & 1.2 & 7.3 \\
\hline II & 83.2 & 72.9 & 21.3 & 16.2 & 33.6 & 1.7 & 10.3 \\
\hline III & 94.0 & 91.9 & 13.2 & 2.3 & 73.9 & 2.5 & 2.0 \\
\hline
\end{tabular}

I: Natural Grazing; II: Natural Grazing Plus sida alba; III: Natural Grazing Plus Concentrate.

GNSC: Groundnut Seed Cake; DM: Dry Matter; OM: Organic Matter CP: Crude Protein; CF: Crude Fiber; EE: Ether Extract; NFE: Nitrogen Free Extract

Table 3: Performance of desert sheep lambs on natural grazing with Sida alba biomass supplemented.

\begin{tabular}{|c|c|c|c|c|}
\hline Parameter & I & II & III & SE \\
\hline No of animal & 5 & 4 & 5 & - \\
\hline Days of trial & 60 & 60 & 60 & - \\
\hline Initial weight & 18.4 & 18 & 19 & 0.73193 \\
\hline Final weight & 21 & 21.3 & 24.4 & 0.93426 \\
\hline Total weight gain & 2.6 & 3.3 & 5.4 & 0.50469 \\
\hline Daily weight gain & 0.0428 & 0.0538 & 0.5890 & 0.10185 \\
\hline Daily feed intake & 1316.73 & 1381.5 & 1207.65 & 45.1765 \\
\hline
\end{tabular}

Table 4: In vitro dry matter and organic Matter digestibility of rations as affected by the level of Sida alba leaves hay.

\begin{tabular}{|c|c|c|c|}
\hline Feed type & Dry matter & Organic matter & SE \pm \\
\hline I & 56.45 & 59.55 & 3.44 \\
\hline II & 65.67 & 68.61 & 2.16 \\
\hline III & 51.45 & 54.65 & 4.32 \\
\hline
\end{tabular}

the three ration where ration had highest DMD value followed by ration I and the lowest \%was for ration III. Organic matter digestibility also followed the same trend where ration II had the highest organic matter digestibility followed by ration I and lowest DMD for ration III. In vitro, organic matter digestibility coefficients were $59.55,68.61$ and $54.65 \%$ for ration I, II and III respectively.

\section{Biomass from Sida alba}

The results have indicated that a fully grown plant can produce 84.910 in one cut. It was estimated that an optimum stand can give a plant in half square meter $\left(\mathrm{m}^{2}\right)$ or 8,400 plant / feddan (20,000/hectare). The expected amount of biomass in one cut was $713 \mathrm{~kg}$ approximately from one feddan $(1.697$ ton per hectare). Hence this drought tolerant species is of great potential for production of biomass that can supplement grazing ruminants on low quality roughage especially during dry season. The amount of biomass estimated here is comparable to that of results reported by $[7,8,17]$ whom found that Ailanthesis excelsa could produce similar amount of biomass.

\section{Conclusion}

The study concluded that Sida alba in rations increase the weight while reducing the cost of nutrition, although reduced consumption of sheep feeding amounts, feed intake which were sufficient items to maintain the rates of gain in live weight.

Citation: Ebahiem MA, Hamed H, Salah Bukhri SA, Abdalla Mohamed SE, Hammad Dahia SB, et al. (2021) Biomass production and nutritive value of Sida alba leaves fed to desert sheep. Int J Vet Sci Res 7(2): 211-215. DOI: https://dx.doi.org/10.17352/ijvsr.000102 


\section{References}

1. El-Hag FM, Fadlalla B, Mukhtar HK (2001) Some production characteristics of Sudan desert sheep under range condition in north Kordofan, Sudan. Trop Anim Health Prod 33: 229-239. Link: https://bit.ly/3pGFh7i

2. Khatir AA, Jadalla JB (2014) Assessment of rangelands biomass using Remote Sensing and Geographical Information System (GIS) in Kordofan Sudan. University of Kordofan Journal of Natural Resources and Environmental Studies. UKJNRES 1: 60-70. Link: https://bit.ly/3Hqvk3V

3. Williamson G, Payne WJA (1975) Animal production in the tropics. $2^{\text {nd }}$ ed London, Longmans, Green \& Co. Ltd.

4. Ministry of Animal Resources and Fishery Annual Report (2019) Department of Strategy Planning. Khartoum, Sudan.

5. Hiendleder S, Mainz K, Plante Y, Lewalski H (2007) Analysis of mitochondrial DNA indicates that domestic sheep are derived from two different ancestral maternal sources: no evidence for contributions from urial and argali sheep. Journal of Heredity 89: 113-120. Link: https://bit.ly/3pCTEto

6. Wilson T (1981) Management and productivity of sheep and goats in traditional systems of the tropics. Int Symp Anim Prod Tropics. Univ Gezira Wad Medani the Sudan 21-25.

7. Abdurrahaman A (2007) Animal Production in Sudan. Sudan University for Science and Technology, Khartoum, Sudan.

8. Suleiman AH, El Tahir AK (1984) Preliminary study on milk production and quantity in some tribal breeds of Sudan Desert sheep, Sudan. J Vet Sci Anim Husb 24: 94-100.
9. El Khidir OA, Khalafalla A (1989) The effect of feeding diets of variable energy concentration on growth and carcass composition of the sudan desert lambs. Sudan J Amin Prod 1: 81-88. Link: https://bit.ly/3HmA1Md

10. Suleiman AH, Eisawi MA (1984) Reproductive performance of some tribal breeds of Sudan Desert sheep under irrigated conditions, Sudan, J Vet Sci Anim Husb 24: 8-91.

11. Jadalla JB (2012) Effects of Supplementation of the Dry Season Grazing with Groundnut Haulms on Nutrients Utilization and Sheep Performance in West Kordofan State, Sudan. J Anim Prod Adv 2: 462-468.

12. Jadalla JB (1995) Effects of supplementation of the dry season Grazing with groundnut haulms on Feed intake Nutrient digestibility and sheep performance in North Kordofan, Sudan. M Sc thesis, Faculty of Animal Production, University of Khartoum, Sudan.

13. Mohamed TA, Salih FE (1991) The Effects of the Stage of maturity on Nutritive Value of Low rainfall woodland savannah pasture, Sudan. Journal of Animal Production 4: 23-36

14. Wilson RT (1987) Livestock production in central Mali, environmental factors affecting weight in traditionally managed goat and sheep. Amin Prod 45: 223232. Link: https://bit.ly/3sGLrq8

15. Association of Official Analytical Chemists (2002) The official Methods of analysis. $16^{\text {th }}$ ed, Washington DC, USA. Link: https://bit.ly/3mF7j15

16. Steel RG, Torrie JH (1996) Principles and procedures of statistics. $2^{\text {nd }}$ ed. Prentice-Hall of India, New Delhi. 231-235.

17. Snecedor GW, Cochran WG (1980) The Statistical Methods The lowa State. University Press. USA. Link: https://bit.ly/3mLy5Fn
Discover a bigger Impact and Visibility of your article publication with Peertechz Publications

\section{Highlights}

* Signatory publisher of ORCID

* Signatory Publisher of DORA (San Francisco Declaration on Research Assessment)

* Articles archived in worlds' renowned service providers such as Portico, CNKI, AGRIS, TDNet, Base (Bielefeld University Library), CrossRef, Scilit, J-Gate etc.

* Journals indexed in ICMJE, SHERPA/ROMEO, Google Scholar etc.

* OAI-PMH (Open Archives Initiative Protocol for Metadata Harvesting)

* Dedicated Editorial Board for every journal

* Accurate and rapid peer-review process

* Increased citations of published articles through promotions

* Reduced timeline for article publication

Submit your articles and experience a new surge in publication services (https://www.peertechz.com/submission). 